\title{
Copper (Cu) and Zinc (Zn) Nutrient Status of Soybean [Glycine max (L.) Merill] Growing Soils in Northern Transitional Zone of Dharwad Taluk (Karnataka), India
}

\author{
B. Chandra Sheker ${ }^{1 *}$, B.M. Radder ${ }^{1}$, V.B. Kuligod ${ }^{1}$, Y.R. Aladakatti ${ }^{2}$ and Jana Harish ${ }^{3}$ \\ ${ }^{1}$ Department of Soil Science and Agricultural Chemistry, College of Agriculture, University of \\ Agricultural Sciences, Dharwad, Karnataka - 580005, India \\ ${ }^{2}$ Department of Agronomy, AICRP on Cotton, ARS, Dharwad farm, UAS, \\ Dharwad, Karnataka, India \\ ${ }^{3}$ Department of Irrigation Water Management, University of Mahatma Phule Krishi Vidyapeeth, \\ Rahuri, Maharashtra, India \\ *Corresponding author
}

\section{A B S T R A C T}

The study was carried out to the status of micronutrients status $(\mathrm{Cu}$ and $\mathrm{Zn})$ in soybean growing soils of Dharwad taluk during 2015-16 kharif season. The study area is situated in

\section{Keywords}

Available $\mathrm{Cu}, \mathrm{Zn}$ and Soybean growing soils

Article Info

Accepted:

23 August 2017

Available Online:

10 September 2017 Northern Transitional Zone (Zone-8) of North Karnataka. For this purpose fifty one surface soil samples were collected by a systematic sampling strategy (by following standard procedure) at the time of harvesting the kharif crop by using GPS in Dharwad taluk. Surface soil samples $(0-15 \mathrm{~cm})$ were collected and subjected to laboratory for analyzing status of available micronutrients viz., $\mathrm{Cu}$ and $\mathrm{Zn}$. Based on the average grain yields in 51 fields, the entire group was divided into below average and above average yield categories. Mean yield of 51 fields was $14.67 \mathrm{q} \mathrm{ha}^{-1}$. The study revealed that the available $\mathrm{Cu}$ content ranged from 0.31 to 1.22 and with mean value of $0.68 \mathrm{mg} \mathrm{kg}^{-1}$ in below average yield category and in above average yield category ranged from 0.32 to 1.12 and with a mean value of $0.68 \mathrm{mg} \mathrm{kg}^{-1}$. Zinc content ranged from 0.13 to 0.29 and with mean value of $0.19 \mathrm{mg} \mathrm{kg}^{-1}$ in below average yield category and in above average yield category ranged from 0.18 to 1.48 and with a mean value of $0.68 \mathrm{mg} \mathrm{kg}^{-1}$. The soil samples are 100 per cent sufficient in copper and samples are deficient in 86.27 per cent and 13.73 per cent soils are sufficient in zinc.

\section{Introduction}

Soybean [Glycine max (L.) Merill], being the "Golden Bean", of the $20^{\text {th }}$ century is a species of legume, native to East Asia, widely grown for its edible bean which has numerous uses. Soybean is one of the nature's most versatile and fascinating crop in the present farming system of Indian agriculture. An increase in population pressure increased thedemand of edible oil greatly in last decade.
As a result there is an increase in the area of oil seed crops in the country. Among the oil seed crops, Soybean is largely popularized in recent years in the country as well as in Karnataka. The popularity of soybean among farmers community may be because of soybean is one of the efficient nitrogen fixer (61-337 $\mathrm{kg} \mathrm{N} \mathrm{ha}^{-1}$ ) among the legumes. The soybean contains high protein $(40-43 \%)$, oil 
content (24-26\%) and also consists of high percentage of amino acids which are essential in human nutrition. In addition to this, soybean protein has five per cent lysine, which is deficient in most of the cereals and enriching the cereal flour with soybean improves the nutritive quality.

Karnataka is one of the major soybean growing state occupying about 2.470 lakh ha with an annual production of 3.001 lakh MT with the productivity of $1215 \mathrm{~kg} \mathrm{ha}^{-1}$ (Anonymous, 2014). In India, major soybean producing states are Madhya Pradesh, Uttar Pradesh, Rajasthan, Gujarat, Maharashtra, Andhra Pradesh and Karnataka. Being an easy care crop, it is widely acceptable by majority of farmers and it gets its preference for all type of soils (Jagdish and Hajare, 1992). Introduction of soybean has led to a shift in the cropping system from fallow-wheat/ chickpea to soybean-wheat/chickpea system (Jagdish and Singh, 1997). This has resulted in an enhancement in the cropping intensity and increase in the profitability per unit land area but frequent growing of soybean has induced widespread deficiency of nutrients in soils (Paroda, 1999) and in turn plateauing/decrease in productivity. Soybean being oilseed legume besides phosphorus and sulphur some of the micronutrients like $\mathrm{Zn}$, $\mathrm{Fe}, \mathrm{Mn}$ and $\mathrm{Cu}$ are required to improve and sustain performance of the soybean crop.

Copper is involved in chlorophyll formation and is a part of several enzymes. It is also required for symbiotic nitrogen fixation. Zinc is required in protein synthesis and for ensuring seed quality and uniform maturity. In the time since 1932, zinc has been found to be a vitally important micronutrient in crop production and deficiencies of this element have been shown to be more widespread throughout the world than those of any other micronutrient (Lantican et al., 2001). Adsorption mechanisms play a very important role in the soil-plant relationships of zinc.
These mechanisms control the concentrations of zinc in the soil solution, and hence that which is immediately available to plant roots, and also the amounts of zinc in labile forms which can be desorbed and become available to plants.

\section{Materials and Methods}

\section{Location of the study area}

The study area is Dharwad taluk in Dharwad district, Karnataka. The study area lies between $15^{\circ} 21^{\prime}$ to $15^{0} 31^{\prime} \mathrm{N}$ latitude and $74^{\circ}$ $48^{\prime}$ to $75^{\circ} 9^{\prime} \mathrm{E}$ longitude. The location of study the area is presented in figure 1 . The study area is situated in Northern Transitional Zone (Zone-8) of North Karnataka. The location of soil samples in selected villages of Dharwad taluk are presented in figure 2. The area receives a mean annual rainfall of 716.2 $\mathrm{mm}$.

\section{Collection of soil samples}

In order to study the micronutrient status of available $\mathrm{Cu}$ and $\mathrm{Zn}$ in soils from Dharwad taluk, fifty one surface soil samples $(0-15 \mathrm{~cm}$ depth) were collected during 2015-16 kharif season. The sample location was recorded by using a GPS.

\section{Methodology}

Micronutrient cations viz., $\mathrm{Cu}$ and $\mathrm{Zn}$ in soils were determined as per the procedure described by Lindsay and Norvell (1978). For this analysis $20 \mathrm{~g}$ finely sieved soil was shaken in $40 \mathrm{ml}$ of $0.005 \mathrm{M}$ DTPA solution (Diethylene Triamine Pentaacetic acid containing $0.1 \mathrm{M}$ triethanol amine and $0.01 \mathrm{M}$ calcium chloride, adjusted to $\mathrm{pH} 7.3$ with $\mathrm{HCl})$ for two hours and filtrate through Whatman No. 42 filter paper and clear filtrate was collected. The filtrate was used for measurement of $\mathrm{Cu}$ and $\mathrm{Zn}$ using atomic absorption spectrophotometer (AAS), at 
different wavelength for $\mathrm{Cu}$ and $\mathrm{Zn}$. Copper and Zinc expressed as $\mathrm{mg} \mathrm{kg}^{-1}$ soil and interpreted as deficient and sufficient by using critical values.

Crop cutting experiment on the fields of selected farmers

Crop cutting experiment from the selected farmers' fields were carried out. In each of the fields at the time of harvest in area of $3 \times 3 \mathrm{~m}$ was selected randomly at three different spots. Plants were uprooted in the selected area and pods were separated from plants, yields were recorded by taking average from all the three spots and expressed in quintals per hectare. Average grain yield of these fifty one fields was calculated. Based on this average grain yield, these fifty one fields were divided into below average yield category and above average yield category.

\section{Results and Discussion}

Results obtained from the present study as well as relevant discussion have been summarized under following heads,

\section{Available Copper $(\mathrm{Cu})$}

The available copper content ranged from 0.31 to $1.22 \mathrm{mg} \mathrm{kg}^{-1}$ with an average of 0.68 $\mathrm{mg} \mathrm{kg}{ }^{-1}$ and standard deviation of 0.262 in below average yield category whereas the available copper content ranged from 0.32 to $1.12 \mathrm{mg} \mathrm{kg}^{-1}$ with an average of $0.68 \mathrm{mg} \mathrm{kg}^{-1}$ and standard deviation of 0.246 in above average yield category (Table 1).

The soils shown that 100 per cent samples were sufficient in available copper (Table 2). Considering the critical limit of $0.2 \mathrm{ppm}$ available copper in soil, all the soils in both the below average and above average yield categories were sufficiently supplied with available copper (Table 1). Similar results were reported by Srikanth et al., (2008) for soils of Northern Karnataka and Pulakeshi et al., (2012).

Soybean grown soils are rarely found deficient in copper content. Similar results were also reported by Gajare et al., (2013) soybean growing soils are sufficient in available copper.

Table.1 DTPA extractable micronutrients $(\mathrm{Cu}$ and $\mathrm{Zn})$ status $\left(\mathrm{mg} \mathrm{kg}^{-1}\right)$ of fifty one soybean growing soils of Dharwad taluk

\begin{tabular}{|l|c|c|}
\hline & Copper $\left(\mathbf{m g ~ k g}^{-\mathbf{1}}\right)$ & Zinc $\left(\mathbf{m g ~ k g}^{-\mathbf{1}}\right)$ \\
\hline \multicolumn{3}{|c|}{ Below average yield category } \\
\hline Minimum & 0.31 & 0.13 \\
\hline Maximum & 1.22 & 0.29 \\
\hline Mean & 0.68 & 0.19 \\
\hline Standard deviation & 0.262 & 0.043 \\
\hline \multicolumn{3}{|c|}{ Above average yield category } \\
\hline Minimum & 0.32 & 0.18 \\
\hline Maximum & 1.12 & 1.48 \\
\hline Mean & 0.68 & 0.68 \\
\hline Standard deviation & 0.246 & 0.385 \\
\hline
\end{tabular}


Table. 2 Number of samples under deficient and sufficient for $\mathrm{Cu}$ and $\mathrm{Zn}$ of surface soil samples from soybean growing soils of Dharwad taluk

\begin{tabular}{|l|c|c|c|}
\hline Nutrient & Total No. of samples & \multicolumn{2}{|c|}{ Rating } \\
\cline { 3 - 4 } & & D & ND \\
\hline Copper $(\mathrm{Cu})$ & 51 & $0.00(0.00)$ & $51(100)$ \\
\hline Zinc $(\mathrm{Zn})$ & 51 & $44(86.27)$ & $7(13.73)$ \\
\hline
\end{tabular}

Note: Figures in parenthesis denote per cent of samples.

Where, D - Deficient, ND - Non deficient

Fig.1 Location of study area

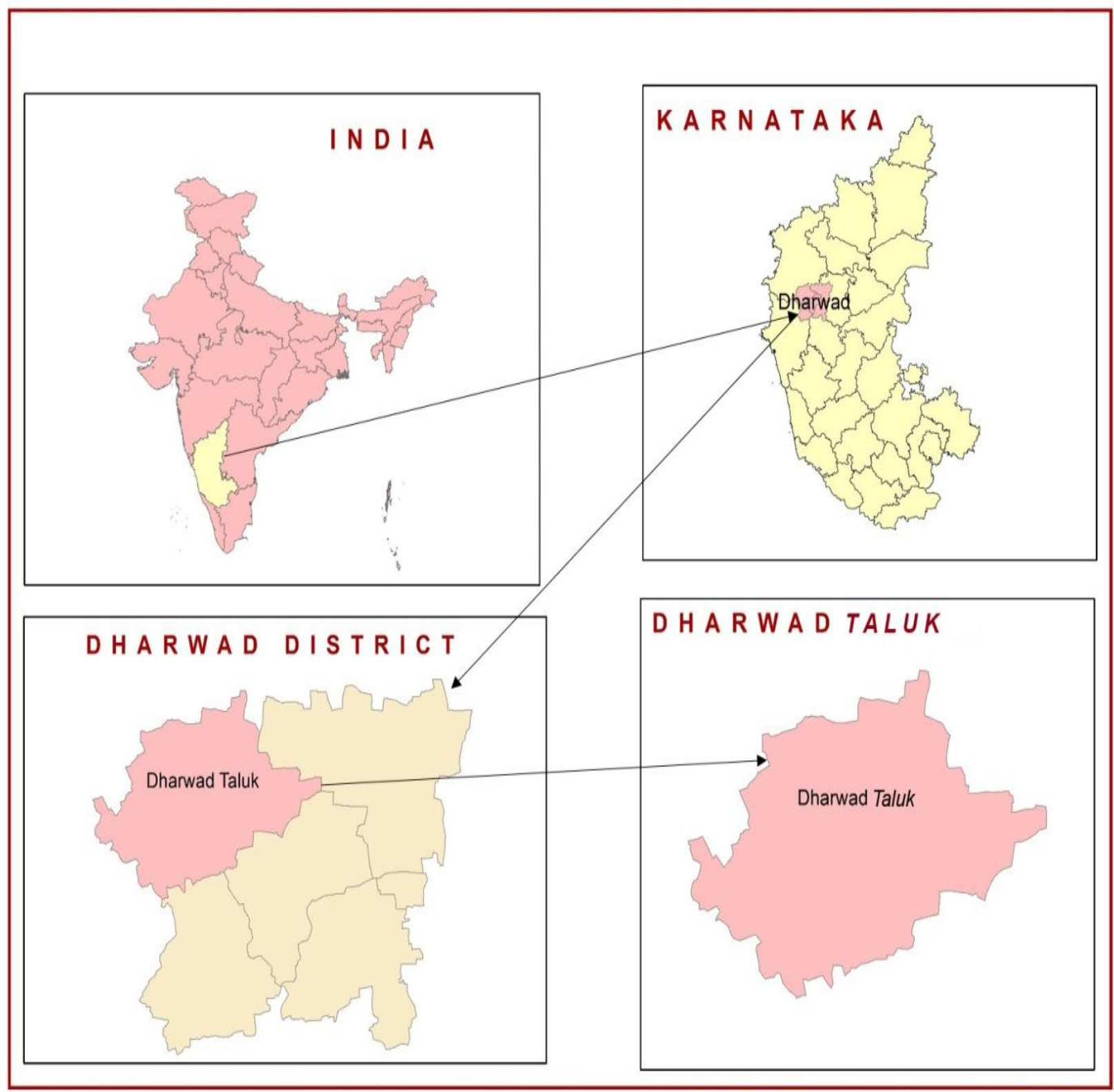


Fig.2 Location of soil samples in Dharwad taluk

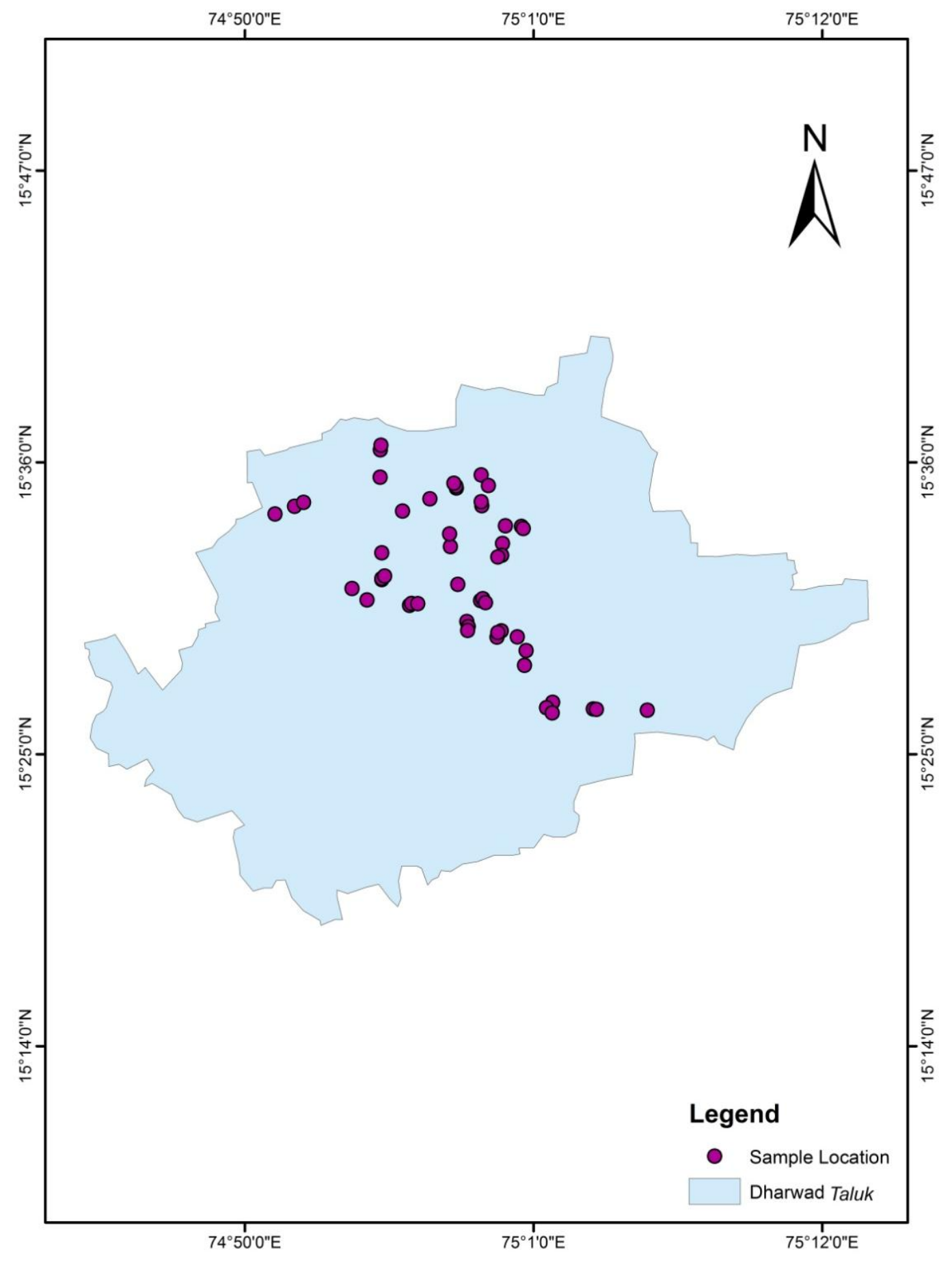

\section{Available Zinc (Zn)}

The available zinc content ranged from 0.13 to $0.29 \mathrm{mg} \mathrm{kg}^{-1}$ with an average of $0.19 \mathrm{mg}$ $\mathrm{kg}^{-1}$ and standard deviation of 0.043 in below average yield category whereas the available zinc content ranged from 0.18 to $1.48 \mathrm{mg} \mathrm{kg}$ 1 with an average of $0.68 \mathrm{mg} \mathrm{kg}^{-1}$ and standard deviation of 0.385 in above average yield category (Table 1$)$. The soils shown that 86.27 per cent samples were deficient in available zinc (Table 2). 
This could be attributed to intensive cropping without adequate supplementation of zinc carriers (Patil et al., 2011). Moreover, phosphorus buildup has been reported in many soils of India due to continuous application of high analysis NPK fertilizers especially phosphatic fertilizers such as DAP with low phosphate use efficiency (15-20\%) in the soils (Swarup, 1998). This might have aggravated phosphorous induced zinc deficiencies in the soils and crops as there exists an antagonistic relationship between available phosphorus and zinc.

The soybean growing area in Dharwad taluk shown that soils were sufficiently supplied with 100 and 13.73 per cent in available copper and zinc content and 86.27 per cent samples were deficient in available zinc content of these soils. The nutrient $(\mathrm{Cu}$ and $\mathrm{Zn})$ status in below average yield category was low as compare to above average yield category in the study area of Dharwad taluk.

\section{References}

Anonymous, 2014. Directorate of Economics and Statistics, Department of Agriculture and Cooperation, Ministry of Agriculture, New Delhi.

Gajare, A. S., Dhawan, A. S. and Ghodke, S. K., 2013. Available micronutrient status of soybean growing soils of Latur district. Int. J. Agric. Sci., 9(2): 719-722.

Jagdish, P., and Hajare, T. N., 1992. Performance of two soybean (Glycine max) varieties under different agronomic practices in Vertic Ustocherpts soils of Vidarbha. Indian Agron. J., 37(2): 366-
368.

Jagdish, P., and Singh, S. B., 1997. A study on adoption of improved technology in Malwa region. Agric. Sci. Dig., 17: 223226.

Lantican, M. A., Pringali, P. L., and Rajaram, S., 2001. Are marginal wheat environments catching up, CYMMIT World Wheat Overview and Outlook. Part 2, 39-44.

Lindsay, W. L., and Norwell, W. A., 1978. Development of DTPA test zinc, iron, manganese and copper. Soil Sci. Soc. American J., 42: 421-428.

Paroda, R. S., 1999, Status of soybean research and development in India. In Proceedings of VI World Soybean Research Conference (H. E. Kauffman, Ed.), Chicago, IL, USA, pp. 13-23.

Patil, S. S., Patil, V. C. and Al-Gaadin, K. A., 2011, Spatial variability in fertility status of surface soils. World Appl. Sci. J., 14(7): 1020-1024.

Pulakeshi, H. B. P., Patil, P. L., Dasog, G. S., Radder, B. M., Bidari, B. I., And Mansur, C. P., 2012, Mapping of nutrients status by Geographic Information System (GIS) in Mantagani village under northern transitional zone of Karnataka. Karnataka J. Agric. Sci., 25(3): 332-335.

Srikanth, K. S., Patil, P. L., Dasog, G. S. and Gali, S. K., 2008. Mapping of available major nutrients of a microwatershed in northern dry zone of Karnataka. Karnataka J. Agric. Sci., 21(3): 391-395.

Swarup, A., 1998. Emerging soil fertility management issues for sustainable crop production in irrigated system: In Long term fertility management through IPNS. Indian Soc. Soil Sci., Bhopal, India. pp. 54-68.

\section{How to cite this article:}

Chandra Sheker, B., B.M. Radder, V.B. Kuligod, Y.R. Aladakatti and Jana Harish. 2017. Copper $(\mathrm{Cu})$ and Zinc $(\mathrm{Zn})$ Nutrient Status of Soybean [Glycine max (L.) Merill] Growing Soils in Northern Transitional Zone of Dharwad Taluk (Karnataka), India. Int.J.Curr.Microbiol.App.Sci. 6(9): 2151-2156. doi: https://doi.org/10.20546/ijcmas.2017.609.265 